De rol van de mensenrechten in het buitenlandse beleid van Nederland na 1945: politicologische en historische literatuur

\title{
MAARTEN KUITENBROUWER
}

\section{Inleiding}

Toen op 16 april 2002 het kabinet-Kok II aftrad naar aanleiding van het NIOD-rapport over Srebrenica was dat de eerste keer in de Nederlandse parlementaire geschiedenis dat een regering viel vanwege een mensenrechtenkwestie in het buitenlands beleid. Dat was al twee keer eerder bijna het geval geweest: bij het kabinet-Den Uyl vanwege de interne verdeeldheid over de levering van kernreactorvaten aan Zuid-Afrika en bij het kabinet-Van Agt I vanwege een conflict met de Tweede Kamer over de afkondiging van een eenzijdige olieboycot tegen Zuid-Afrika.

De val van het kabinet-Kok II vanwege Srebrenica biedt een goede historische aanleiding om de recente literatuur over de rol van de mensenrechten in het naoorlogse buitenlandse beleid van Nederland eens op een rij te zetten. Daarbij gaat het in de eerste plaats om de politicologische literatuur, die in tegenstelling tot een aantal recente historische dissertaties in dit historische vaktijdschrift buiten beschouwing is gebleven. De centrale vraag luidt in hoeverre politicologische en historische benaderingen elkaar aanvullen waar het de rol van de mensenrechten in het Nederlandse buitenlandse beleid betreft.

Dit besprekingsartikel is dus, zoals oud-premier Lubbers het placht uit te drukken, vanuit een 'positieve grondhouding' geschreven. De wetenschapsantropoloog Becher heeft op geestige wijze aangetoond dat 'academische stammen' hun eigen 'stamgebied' scherper plegen te markeren, naarmate ze zich meer met dezelfde onderwerpen gaan bezighouden. 1 Dat leidt vaak tot een vruchteloze polemiek, waarbij men een karikatuur van elkanders discipline bestrijdt. Een typerend voorbeeld vormde de volstrekt zinloze onaangenaamheden die de historicus Brands ${ }^{2}$ en de politicoloog Siccama ${ }^{3}$ enkele jaren geleden uitwisselden op het terrein van vrede en veiligheid. ${ }^{4}$ In dit besprekingsartikel zal het primair over de overeenkomsten tussen beide vakgebieden gaan, hoewel de verschillen uiteraard niet verdoezeld mogen worden.

Drie recente politicologische studies zullen centraal staan in dit besprekingsartikel: het overzicht van Baehr, Castermans-Holleman en Grünfeld ${ }^{5}$ over de rol van de men-

1 T. Becher, Academic trihes and territories. Intellectual enquiry and the cultures of disciplines (Buckingham, 1996) 38-40.

2 M. Brands, The obsolescence of almost all theories concerning international relations (Wassenaar, 1997).

3 J. G. Siccama, 'Een andere wereld; een andere polemologie?', Transaktie, XXVI (1997) 177-185.

4 Zie ook de kritiek van B. Lieshout en J. de Wilde, met een repliek van Brands in het themanummer 'Nieuwste Geschiedenis en Internationale Betrekkingen', De Nieuwste Tijd (juni 1998) 19-45.

5 P. Baehr, M. Castermans-Holleman, F. Grünfeld, Human rights in the foreign policy of the Netherlands (Antwerpen, Oxford, New York, 2002). 
senrechten in het Nederlandse buitenlandse beleid na 1973, de dissertatie van Esther van den Berg ${ }^{6}$ over de invloed van binnenlandse pressiegroepen op het Nederlandse mensenrechtenbeleid ten aanzien van Zuid-Afrika en Indonesië en de dissertatie van Yvonne Kleistra ${ }^{7}$ over beleidverandering op het ministerie van buitenlandse zaken, waarin een belangrijke casestudy is opgenomen over het Nederlandse Surinamebeleid na 1975. De historische studies die primair als vergelijkingsmateriaal zullen fungeren zijn de drie Utrechtse dissertaties waarin het Nederlandse mensenrechtenbeleid door Malcontent ${ }^{8}$ voor de Derde Wereld, door De Boer ${ }^{9}$ voor Zuid-Afrika en Baudet ${ }^{10}$ voor Oost-Europa is uitgewerkt. Een multidisciplinaire congresbundel over de geschiedenis van de mensenrechten bevatte naast bijdragen van historici als Malcontent, De Boer, De Goede, Maters, Leenders en mijzelf over Nederlands beleid ook een politicologische bijdrage over het zelfbeschikkingsrecht van Baehr. ${ }^{11}$

\section{Besluitvormingsanalyse}

Vrijwel alle studies die over het Nederlandse mensenrechtenbeleid na 1945 verschenen zijn, niet alleen de drie bovengenoemde politicologische studies, maar ook de drie historische dissertaties, gaan in meer of mindere mate uit van de 'decision making analysis' in de leer van de internationale betrekkingen. ${ }^{12}$ Deze benadering kwam begin jaren zestig op als reactie op het dominante 'state as actor' model in de toenmalige Amerikaanse politicologie. De staat vormde volgens de aanhangers van de 'decision making analysis' zelden een eenheid. Bij besluitingsprocessen in het buitenlandse beleid was een reeks van spelers betrokken, elk met hun eigen belangen en doelstellingen. Klassiek is de studie van Allison over de Amerikaanse besluitvorming tijdens de Cuba-crisis van 1962, waarin hij duidelijk de meerwaarde aantoonde van de 'decision making analysis' ten opzichte van de traditionele 'state as actor' benadering en het aan de economie ontleende 'rational choice' model. ${ }^{13}$

Overigens bevatte de 'decision making analysis' voor traditionele historici die de moeite namen om er kennis van te nemen veel bekends. $\mathrm{Zij}$ waren reeds gewend om verschillende staatsrechtelijke instituties als staatshoofd, kabinet en parlement in hun

6 E.M. van den Berg, The influence of domestic NGOs on Dutch human rights policy. Case studies on South Africa, Namibia, Indonesia and East Timor (Antwerpen, Groningen, Oxford, 2001 ).

$7 \quad$ Y. Kleistra, Hollen of stilstaan. Beleidsverandering bij het Nederlandse ministerie van buitenlandse zaken (Delft, 2002).

$8 \quad$ P. A. M. Malcontent, Op kruistocht in de derde wereld. De reacties van de Nederlandse regering op ernstige en stelselmatige schendingen van fundamentele mensenrechten in ontwikkelingslanden, 1973 1981 (Hilversum, 1998).

9 S. de Boer, Van Sharpeville tot Soweto. Nederlands regeringsbeleid ten aanzien van apartheid, 19601977 (Den Haag, 1999).

10 F. Baudet, 'Het heeft onze aandacht'. Nederland en de rechten van de mens in Oost-Europa en Joegoslavië, 1972-1989 (Amsterdam, 2001).

11 M. Kuitenbrouwer, M. Leenders, ed., Geschiedenis van de mensenrechten. Bouwstenen voor een interdisciplinaire benadering (Hilversum, 1996).

12 Vgl. P. R. Viotti, M. V. Kauppi, International relations theory. Realism, pluralism, globalism (New York, Toronto, 1993) 223-239.

13 G. T. Allison, Essence of decision. Explaining the Cuban missile crisis (Boston, 1971). 
studie van de buitenlandse politiek te betrekken, veelal aangevuld met krantenonderzoek. Maar politicologische beoefenaren van de 'decision making analysis' als Allison wezen ook op informele instituties, zoals verschillende overheidsbureaucratieën en pressiegroepen. Zowel in de politicologische als de historische studies over de rol van de mensenrechten in het Nederlandse buitenlandse beleid worden analytisch de volgende instituties onderscheiden, die bij de besluitvorming betrokken waren: - de regering en dan vooral de minister van buitenlandse zaken en de minister voor ontwikkelingssamenwerking;

- het ministerie van buitenlandse zaken met zijn verschillende directies en eventueel andere, eveneens gelaagde ministeries;

- het parlement met verschillende partijen en facties;

- pressiegroepen en dan zowel de humanitaire zoals Amnesty International, landencomités en kerken als de economische zoals werkgeversorganisaties en vakbonden; - de media, waarbij naast kranten en tijdschriften de televisie de afgelopen decennia sterk aan invloed heeft gewonnen;

- de publieke opinie, zoals die actief door demonstraties en passief door opinieonderzoek naar buiten treedt.

Over het belang van bovengenoemde instituties en de daarin naar voren tredende personen zijn alle auteurs het wel eens. Maar bij de uitwerking zijn er toch kenmerkende verschillen tussen de politicologische en historische studies waarneembaar. De 'decision making analysis' werd door de politicologen in theoretisch opzicht meer uitgewerkt dan door de historici, terwijl deze analyse door de historici in empirisch opzicht meer werd uitgewerkt dan door de politicologen. Tegen het systematisch uitgevoerde archiefonderzoek van met name het archief van Buitenlandse Zaken en de notulen van de ministerraad steken de gepubliceerde bronnen van de politicologen, aangevuld met interviews, wat mager af. Van den Berg onderzocht weliswaar systematisch de archieven van verschillende pressiegroepen, maar slechts selectief de overheidsarchieven.

In het algemeen hanteren de politicologen hun theoretische concepten ook stringenter dan de historici de hunne. Terwijl de politicologen met hun concepten er naar streven causale relaties vast te stellen, vatten de historici hun theoretische concepten voorzichtiger op - meer in 'attenderende' zin, zoals de historische socioloog Goudsblom het mooi uitdrukte. ${ }^{14}$ Aan predictie waagt in het algemeen vrijwel geen enkele politicoloog zich nog, zodat Brands eerder genoemde kritiek bij publicatie reeds grotendeels achterhaald was.

Bovendien verschillen de drie hier besproken politicologische studies onderling sterk in de mate waarin de 'decision making analysis' theoretisch wordt uitgewerkt. In het overzichtswerk van Baehr, Castermans-Holleman en Grünfeld gebeurde dat doelbewust het minst. Het ging de auteurs vooral om de empirische vraag in hoeverre de praktijk van het mensenrechtenbeleid afweek van de formele doelstelling, vastgelegd in de mensenrechtennota van 1979 en de periodieke vervolgnotities. ${ }^{15}$ In de dissertatie 
van Kleistra beslaat het theoretische tweede deel maar liefst 62 van de 283 pagina's, waarmee het empirische, derde deel met twee casestudies, het Suriname-beleid en het wapenbeheersingsbeleid, nauwelijks verbonden is. Maar hier gaat het dan ook om een bestuurskundige dissertatie. De bestuurskunde is als recente afsplitsing van de politicologie een discipline in wording. Volgens de wetenschapsantropoloog Becher plegen afgescheiden academische stammen hun nieuwe specialisatie vaak in sterke mate theoretisch te legitimeren. ${ }^{16}$ Kleistra's dissertatie werd dan ook kritisch getypeerd als 'een boek voor liefhebbers van theoretische exercities' door Baehr, één van de stamoudsten van de gevestigde Nederlandse politicologie. ${ }^{17}$ Overigens hebben Baehr ${ }^{18}$, Castermans-Holleman ${ }^{19}$ en Grünfeld ${ }^{20}$ in eerdere studies de 'decision making analysis' en daarmee verbonden theoretische concepten zelf ook vrij uitvoerig uitgewerkt, evenals Van den Berg in haar dissertatie over de invloed van pressiegroepen. ${ }^{21}$

\section{De landenstudies}

Alle studies, zowel de politicologische als de historische, zijn empirisch uitgewerkt voor de rol van de mensenrechten in de Nederlandse buitenlandse betrekkingen met bepaalde landen, waar die rechten geschonden werden. De meeste politicologische en historische studies onderzochten de Nederlandse reacties zowel in bilateraal als multilateraal verband. In chronologisch opzicht hebben de politicologische studies een wat langere tijdsduur dan de meer gedetailleerde historische studies. Maar in beide disciplines ligt het accent op de regeringsperiode van de kabinetten Den Uyl (19731977) en Van Agt I (1977-1981), toen de mensenrechten tot één van de officiële doelstellingen van het Nederlandse buitenlands beleid werden verheven.

Tijdens het kabinet-Den Uyl streefden de PvdA-bewindslieden op Buitenlandse Zaken Max van der Stoel en Jan Pronk ieder op eigen wijze actief de mensenrechten na, terwijl door het kabinet-Van Agt I onder druk van de Tweede Kamer de bevordering van de mensenrechten als doelstelling van het buitenlands beleid formeel werd vastgelegd in de mensenrechtennota van 1979. ${ }^{22}$ 'De regering ziet de bevordering van de rechten van de mens als een wezenlijk onderdeel van haar buitenlands beleid', aldus de nota. Maar daar werd direct aan toegevoegd dat ook andere doelstellingen, zoals vrede en veiligheid en economische betrekkingen, van wezenlijk belang waren voor het buitenlands beleid. In verschillende vervolgnotities bevestigden opeenvolgende kabinetten van verschillende politieke kleur dit uitgangspunt.

\footnotetext{
16 Becher, Academic tribes, 43-45.

17 P. Baehr, 'Heeft het Nederlandse ministerie van buitenlandse zaken nog bestaansrecht?', Internationale Spectator, LVI (2002) 517-518.

18 P. R. Baehr, The role of human rights in foreign policy (Basingstoke, Londen, 1994) 3-83.

19 M. C. Castermans-Holleman, Het Nederlands mensenrechtenbeleid in de Verenigde Naties (Den Haag, 1992)47-83.

20 F. Grünfeld, Nederland en het Nabije Oosten. De Nederlandse rol in de internationale politiek ten aanzien van het Arabisch-Israëlisch conflict 1973-1982 (Deventer, 1991) 1-57.

21 Van den Berg, Influence of domestic NGOs, 19-48.

22 'De rechten van de mens in het buitenlands beleid', Handelingen Tweede Kamer, 1978-1979,15571, nrs. $1-2$.
} 
Hoe wezenlijk de mensenrechten in verhouding tot andere doelstellingen van buitenlands beleid in de praktijk geweest zijn, vormt de centrale vraag van de studie van Baehr, Castermans-Holleman en Grünfeld. Van de besproken literatuur heeft hun studie de grootste reikwijdte. Zij behandelen voor de periode 1973 tot 2000 de rol van de mensenrechten in de Nederlandse betrekkingen met achtereenvolgens Argentinië (Grünfeld), Chili (Grünfeld), Midden-Amerika (Grünfeld), Turkije (CastermansHolleman), de Sovjetunie (Baehr en Baudet), China (Castermans-Holleman), Indonesië (Baehr) en Zuid-Afrika (Baehr).

Zoals gezegd biedt de dissertatie van Kleistra een belangrijke aanvulling met haar casestudy over het Suriname-beleid, vooral van belang voor de vergelijking met het Indonesië-beleid. Maar de belangrijkste omissie van de overzichtsstudie van Baehr, Castermans-Holleman en Grünfeld is het doelbewust weglaten van Srebrenica. De auteurs merken hierover op: 'This episode,' which has been termed 'Europe's worst massacre since the Second World War', has led to an agonizing reappraisal of Dutch involvement in UN peace-keeping activities, but is not generally seen as a prime example of human rights policy. ${ }^{23}$ Die laatste bewering is onhoudbaar en heeft een sterke, vertekenende invloed op hun hoofdconclusie dat Nederland sinds de jaren zeventig in de praktijk steeds minder betekenis aan de mensenrechten in het buitenlandse beleid is gaan hechten. Dit afgezien van het feit dat de Nederlandse inzet in Srebrenica vergezeld ging van een bijdrage aan de redelijk geslaagde VN-vredesoperaties in Cambodja en Haïti en gevolgd werd door een bijdrage aan de eveneens redelijk geslaagde $\mathrm{VN}$-vredesoperatie in het grensgebied tussen Ethiopië en Eritrea.

Het valt de auteurs niet kwalijk te nemen dat ze de publicatie van hun verder zeer nuttige, Engelstalige overzichtswerk niet wilden uitstellen tot ze de 3400 pagina's van het NIOD-rapport over Srebrenica konden lezen. Maar op grond van de twee jaar eerder verschenen studie van Both drong de conclusie zich al op dat de inzet van Dutchbat in de zogenaamde safe haven van de VN in sterke mate door morele, humanitaire motieven bepaald werd en door regering, parlement en publieke opinie als een mensenrechtenkwestie ervaren werd. ${ }^{24}$ Reeds tijdens de jaren die voorafgingen aan de val van Srebrenica waren de vergelijkingen van de burgeroorlog in het voormalige Joegoslavië met de Tweede Wereldoorlog niet van de lucht. Dat de Nederlandse Srebrenica-missie zo jammerlijk mislukte staat in analytisch opzicht los van het hoge mensenrechtengehalte van de voorafgaande meningsvorming en besluitvorming. In psychologisch opzicht was er natuurlijk wel een verband. Juist die sterke mate van preoccupatie met de mensenrechten maakte veel opiniemakers en besluitvormers in Nederland ziende blind voor de grote risico's die aan de inzet van Dutchbat in Srebrenica verbonden waren, zoals ook de verkorte publieksversie van het NIOD-rapport aantoont. ${ }^{25}$ De analyse van het Nederlandse beleid ten aanzien van mensenrechtenschendingen kan niet alleen van de successen, maar ook van de mislukkingen iets leren.

23 Baehr, Castermans-Holleman, Grünfeld, Human rights, 233.

24 N. Both, From indifference to entrapment. The Netherlands and the Yugoslav crisis 1990-1995 (Amsterdam, 2000) 143-223.

25 P. Bootsma, Srebrenica. Het officiële NIOD-rapport samengevat (Leiden, 2002) 85-133. 
Behalve deze fundamentele kritiek is er echter niets dan waardering mogelijk voor de acht casestudies die de auteurs wél behandelden en hun overige, goed gefundeerde conclusies. Veel van het gene dat in de cases Chili, Indonesië, Zuid-Afrika en de Sovjetunie vermeld wordt, is al bekend uit de historische dissertaties van respectievelijk Malcontent, De Boer en Baudet. Maar de uitkomsten van hun archiefonderzoek zijn nu voor een internationaal publiek toegankelijk gemaakt. De overige vier casestudies zijn voor een groot deel op origineel materiaal gebaseerd. Dat geldt met name voor de bijdragen van Castermans-Holleman over Turkije en China, die bovendien beide een hoge actualiteitswaarde hebben. Slechts enkele keren is er behoefte aan enige historische aanvulling bij de acht landenstudies.

Zo wijdt Grünfeld slechts één, weliswaar lange noot aan het staartje dat de terughoudende Nederlandse reactie op het Videla-regime eind jaren zeventig, begin tachtig bleek te hebben in de vorm van de 'zaak-Zorreguieta' in 2000-2001. ${ }^{26}$ In het slechts terloops vermelde onderzoeksrapport-Baud kwam overigens ook de Tweede Wereldoorlog weer om de hoek kijken. ${ }^{27}$ Maar Grünfelds vergelijking tussen de lauwe reactie op de Videla-coup in Argentinië en de heftige reactie op de Pinochet-coup in Chili is bijzonder instructief als het gaat om de rol van interne factoren als progressieve identificatiemogelijkheden met het voorafgaande burgerbewind ter plaatse, de aanwezigheid van ontwikkelingshulp als sanctie-instrument en het geringe gewicht van de economische betrekkingen. Deze factoren waren wel in het geval van het Chili van Allende aanwezig, maar niet in het geval van Argentinië, met zijn chaotische Peronistische regeringen.

De vergelijking van de Indonesië-studie van Baehr in het overzichtswerk met de Suriname-studie van Kleistra in haar dissertatie is om twee redenen instructief: in de eerste plaats vanwege de doorwerking van het koloniale verleden dat in beide gevallen bijdroeg tot het verlenen van relatief veel Nederlandse ontwikkelingshulp, maar in de tweede plaats vanwege de wisselende betekenis van 'groot' en 'klein' in de internationale betrekkingen, dat deze hulp in het geval van Suriname tot een veel effectiever sanctie-instrument maakte dan in het geval van Indonesië. Voor de ministaat Suriname was Nederland een betrekkelijk grote mogendheid die vrijwel alle ontwikkelingshulp verstrekte. De opschorting van die hulp na de 'december-moorden' in 1982 kon daardoor effectief bijdragen tot het herstel van de democratie in de voormalige kolonie. In het geval van Indonesië was de voormalige kolonisator echter een betrekkelijk kleine mogendheid die verhoudingsgewijs steeds minder bijdroeg aan de omvangrijke hulpinkomsten. De Nederlandse opschorting van enkele kredieten uit protest tegen het bloedbad in Dili (Oost-Timor) leidde dan ook tot verbreking van de ontwikkelingssamenwerking door het Suharto-regime in 1992. Japan nam vervolgens royaal het hele weggevallen Nederlandse hulpaandeel voor zijn rekening.

De dissertatie van Van den Berg over de invloed van binnenlandse pressiegroepen biedt een belangrijke aanvulling op de politicologische en historische literatuur over

26 Baehr, Castermans-Holleman, Grünfeld, Human rights, 23.

27 M. Baud, Militair geweld, burgerlijke verantwoordelijkheid. Argentijnse en Nederlandse perspectieven op het militaire bewind in Argentinië (1976-1983) (Den Haag, 2001) 175-179, 185-187, 195. 
het Nederlandse mensenrechtenbeleid ten aanzien van Indonesië en Zuid-Afrika. Ze behandelt vijf specifieke gevallen die vanaf het einde van de jaren zeventig tot het begin van de jaren negentig speelden in Nederland: de boycot van steenkool uit ZuidAfrika, de frequente doodstraf in Zuid-Afrika, de import van verrijkt uranium uit het door Zuid-Afrika ingelijfde Namibië, de verlate executie van politieke gevangenen in Indonesië die bij de vestiging van het Suharto-regime veroordeeld waren en het bloedbad dat het Indonesische leger eind 1991 in Dili, Oost-Timor aanrichtte.

Niet al haar hypotheses, ontleend aan drie theorieën van collectieve actie, werden bevestigd. Maar haar hoofdconclusie, dat de Nederlandse pressiegroepen wel degeüjk invloed uitoefenden op het buitenlands beleid ten aanzien van de vijf gevallen is goed gefundeerd. Het departement van buitenlandse zaken nam de pressiegroepen, die zowel uit radicale landencomités als meer gematigde mensenrechtenorganisaties zoals Amnesty International, kerken en vakbonden bestonden, serieus, al was het maar als klokkenluiders. Hoe breder de coalitie van pressiegroepen en hoe meer parlementaire steun ze ontvingen, des te groter was hun invloed. Maar in geen enkel geval kwam de Nederlandse regering volledig aan de wensen van de pressiegroepen tegemoet.

Haar eindconclusie luidde:

Because NGOs had an influence on Dutch policy on the selected issues ... it cannot be maintained, as was hypothesised in Chapter I, that Dutch foreign policy in the field of human rights was merely a process of adjusting to international developments. Internal factors, in particular activities by domestic NGOs, were an important determinant of Dutch human rights policy. ${ }^{28}$

Daarmee raakte ze de kern van het debat dat zowel onder politicologen als historici gevoerd wordt over de invloed van interne en externe factoren in de Nederlandse buitenlandse politiek - in het algemeen en in het bijzonder op het terrein van de mensenrechten.

\section{Interne en externe factoren}

De oorsprong van het debat over de invloed van interne dan wel externe factoren ligt in de politicologie, in de handboeken over de Nederlandse buitenlandse politiek, die respectievelijk door de politicologen Voorhoeve en Hellema geschreven werden. In navolging van de Utrechtse historicus Boogman analyseerde Voorhoeve de Nederlandse buitenlandse politiek in 1979 in termen van drie beleidstradities, die uit de zeventiende eeuw zouden stammen: de maritiem-commerciële traditie, de neutralistische afzijdigheidstraditie en de internationalistisch-idealistische traditie, waar de naoorlogse ontwikkelingssamenwerking en het mensenrechtenbeleid een direct uitvloeisel van vormden. ${ }^{29}$ In 1995 leverde Hellema in zijn handboek fundamentele kritiek op deze

28 Van den Berg, Influence of domestic NGOs, 388.

29 J. J. C. Voorhoeve, Peace, profits and principles. A study of Dutch foreign policy (Den Haag, Londen, Boston, 1979) 42-54. 
eenzijdige nadruk op interne factoren. Zijns inziens waren externe factoren over het algemeen veel belangrijker geweest voor Nederland als kleine mogendheid. ${ }^{30}$

Externe factoren als geografische ligging, positie in de wereldeconomie en positie in de internationale machtsstructuur achtte Hellema belangrijker dan interne factoren als de sociaal-economische en partijpolitieke verhoudingen en de persoon van de minister. Hij typeerde het Nederlandse buitenlandse beleid in dit verband als een 'georganiseerde aanpassing' aan internationale ontwikkelingen. De aandacht van het progressieve kabinet-Den Uyl voor de mensenrechten stond volgens Hellema niet op zich zelf. Zowel in de Verenigde Staten onder het presidentschap van Jimmy Carter als in andere Europese landen was dat tijdens de jaren zeventig eveneens het geval.

Vrijwel alle auteurs, zowel de politicologen als de historici, behandelden de tegenstelling Voorhoeve-Hellema en kozen vervolgens een eigen combinatie van zowel interne als externe factoren. Als 'positieve', de rol van de mensenrechten bevorderende factoren worden vaak de 'culturele revolutie' van de jaren zestig, het optreden van pressiegroepen, de toenemende invloed van de tv en de détente in de Koude Oorlog genoemd, als 'negatieve', belemmerende factoren vooral economische belangen en de terughoudendheid van veel westerse bondgenoten inzake mensenrechtenschendingen. Elke auteur legt echter zijn of haar eigen accenten, afhankelijk van het specifieke onderwerp. Voorbeelden van dergelijke specifieke, landgebonden factoren zijn het voortleven van de traditionele stamverwantschap ten aanzien van Zuid-Afrika en het feit dat Nederland na 1967 de diplomatieke belangen van Israël in de Sovjetunie vertegenwoordigde. Door nadere periodisering valt er echter wel een zeker patroon in de bonte rij interne en externe factoren waar te nemen.

Zoals boven al werd opgemerkt leggen vrijwel alle auteurs, zowel de politicologen als de historici, een zekere nadruk op de regeringsperiode van het progressieve kabinetDen Uyl en het centrumrechtse kabinet-Van Agt I, toen de mensenrechten tot doelstelling van Nederlands beleid werden verheven. De historische auteurs besteedden echter meer aandacht aan de voorgeschiedenis dan de politicologen. Dan zijn er tot de cruciale fase 1973-1981 twee voorafgaande fasen waarneembaar. Tijdens de eerste fase, van 1945 tot 1962, was Nederland nog een verzuilde, anticommunistische en koloniale mogendheid die weinig aandacht aan de mensenrechten besteedde. Tijdens de tweede fase, vanaf de afstand van Nieuw-Guinea tot het aantreden van het kabinetDen Uyl, nam de aandacht voor de mensenrechten onder invloed van ondermeer de ontzuiling en de détente toe onder de publieke opinie, de pressiegroepen en het parlement, maar bleef de regering terughoudend. ${ }^{31}$ Dat veranderde tijdens het progressieve kabinet-Den Uyl én het centrumrechtse kabinet-Van Agt I, dat afhankelijk was van de 'gedoogsteun' van de progressieve vleugel van het CDA in de Tweede Kamer.

Tijdens deze cruciale periode, van 1973-1981, treedt uit de literatuur ongeveer de volgende combinatie van interne en externe factoren naar voren. In internationaal opzicht was er sprake van een voortzetting van de détente, tot de Russische inval in

30 D. Hellema, Buitenlandse politiek van Nederland (Utrecht, 1995) 9-11, 43-46, 331-336.

31 Zie in dit verband ook T. de Goede, 'De mensenrechten in het Nederlandse buitenlandse beleid ten aanzien van Spanje, Portugal en Griekenland', in: Kuitenbrouwer, Leenders, Geschiedenis van de mensenrechten, $227-258$. 
Afghanistan in 1979-1980. De oprichting van de CVSE in 1975, waarbij naast vrede en veiligheid en economische samenwerking ook de mensenrechten tot op zekere hoogte als onderdeel erkend werden, zowel door Oost als West, vormde in dit opzicht een hoogtepunt. Als Nederlands minister zette Van der Stoel zich echter niet alleen in voor bevordering van de mensenrechten in het communistische Oostblok, maar ook in de rechtse dictaturen en NAVO-partners Griekenland en Portugal. ${ }^{32}$ Verder leverden talrijke ontwikkelingen in de Derde Wereld, zoals de Pinochet-coup, de opstand in Soweto, de onafhankelijkheid van de Portugese koloniën, de annexatie van OostTimor en de sandinistische revolutie, even zovele impulsen voor binnenlandse mensenrechtenagitatie. Die agitatie werd bevorderd door een complex van interne factoren, zoals de opkomst van de naoorlogse protestgeneratie, de blijvende welvaartstoename ondanks de eerste oliecrisis, de groei van het hoger onderwijs, de algemene verbreiding van de tv, het democratiseringsstreven op allerlei terreinen en tenslotte het seculariseringsproces.

Heldring ${ }^{33}$ typeerde dit complex van interne factoren als een 'culturele revolutie', Righart, Malcontent en ikzelf conceptualiseerden het op een iets hoger abstractieniveau als de doorbraak van een 'postmaterialistisch' waardepatroon, in navolging van de Amerikaanse politicoloog Inglehart. ${ }^{34}$ Dat deze interne factoren toch iets belangrijker waren dan de externe zou men kunnen afleiden uit het feit dat het actieve mensenrechtenbeleid van het progressieve kabinet-Den Uyl grotendeels werd voortgezet door het centrum-rechtse kabinet-Van Agt I, ondanks de herleving van de Koude Oorlog. De totstandkoming van de mensenrechtennota, een betrekkelijk uniek initiatief in westers verband, woog zwaarder dan de stopzetting van de symbolische hulp aan Cuba en de vermindering van de hulp aan Vietnam.

In hoeverre de mensenrechten na publicatie van de mensenrechtennota in 1979 daadwerkelijk een doelstelling van het Nederlandse buitenlandse beleid zijn gebleven, daar lopen de meningen over uiteen. Zoals gezien menen Baehr, Castermans-Holleman en Grünfeld dat dit in afnemende mate het geval was, vooral vanwege economische belangen en de terughoudendheid van veel westerse bondgenoten. ${ }^{35}$ Volgens mij was er in Nederland sprake van continue aandacht voor de mensenrechten. Dit zowel door interne factoren, zoals de voortdurende invloed van een postmaterialistisch waardepatroon in Nederland, ondanks de economische inzinking van de jaren tachtig, als door externe factoren, zoals het einde van de Koude Oorlog. Zelfs de herleving van de Koude Oorlog eind jaren zeventig, begin jaren tachtig, weerhield Nederland er niet van omvangrijke hulp aan het progressieve Nicaragua te verlenen, ondanks

32 M. Kuitenbrouwer, 'Een realistische idealist. Max van der Stoel (1973-1977 en 1981-1982)', in: D. Hellema, B. Zeeman, B. van der Zwan, ed., De Nederlandse ministers van buitenlandse zaken in de twintigste eeuw (Den Haag, 1999) 248-249.

33 J. L. Heldring, 'Nederland in de wereld, 1945-1985',in:N. C. F. van Sas, ed., De kracht van Nederland. Internationale positie en buitenlands beleid in historisch perspectief (Haarlem, 1991) 239-240.

$34 \mathrm{Vgl}$. R. Inglehart, The silent revolution. Changing values and political styles among western publics (Princeton, 1977) en Culture shift in advanced industrial society (Princeton, 1990). Baudet bekritiseerde echter deze binnenlandse verklaring van het buitenlandse mensenrechtenbeleid, Het heeft onze aandacht, 44-46.

35 Baehr, Castermans-Holleman, Grünfeld, Human rights, 233-235. 
Reagans anti-sandinistische beleid. ${ }^{36}$ Deze continue steun voor het sandinistische bewind, ook onder VVD-minister E. Schoo, blijft onderbelicht in Grünfelds studie over Midden-Amerika.

Het einde van de Koude Oorlog, eindjaren tachtig, droeg enerzijds bij tot de beëindiging van de slepende conflicten in Zuidelijk Afrika, Midden-Amerika en IndoChina, maar riep anderzijds nieuwe, etnische conflicten op, vooral in Oost-Europa en Afrika. De Nederlandse deelname aan VN-vredesmissies in Cambodja, Haïti, Bosnië en Ethiopië-Eritrea en aan de NAVO-oorlog tegen Servië vanwege de mensenrechtenschendingen in Kosovo onderstrepen de mijns inziens blijvende betekenis van de mensenrechten als doelstelling van buitenlands beleid.

In Cambodja en Haïti vormden de mensenrechten een hoofddoelstelling van de door Nederland gesteunde VN-vredesmissies tijdens de jaren negentig, omdat ze in het verlengde van de vredeshandhaving de voorbereiding van democratische verkiezingen beoogden. Vooral in Cambodja was dit van groot belang voor de mensenrechten, omdat de vrije verkiezingen onder de hoede van VN-militairen, waaronder een Nederlands mariniersbataljon, het definitieve einde van de Rode Khmer inluidden, die de ernstigste mensenrechtenschendingen ter wereld sinds 1945 op hun geweten hadden. Het hoge mensenrechtengehalte van de Nederlandse inzet tijdens de opeenvolgende burgeroorlogen in ex-Joegoslavië is hierboven al ter sprake gekomen. Hoewel het in het geval van de vredesmissie in het grensgebied tussen Ethiopië en Eritrea om beëindiging van een reguliere oorlog ging, vormde de Nederlandse deelname een belangrijk nationaal en internationaal signaal dat Nederland na het fiasco in Srebenica bereid bleef vredesmissies met een belangrijke humanitaire dimensie actief te steunen, zij het onder stringente voorwaarden. ${ }^{37}$

In het algemeen besteden de politicologische auteurs meer aandacht aan structurele factoren dan aan specifieke personen, zoals uit Hellema's lijstje van externe en interne factoren al bleek. Baehr, Castermans-Holleman en Grünfeld constateren bijvoorbeeld dat de Nederlandse ministers van buitenlandse zaken zich over het algemeen terughoudender opstelden ten opzichte van mensenrechtenschendingen dan hun collega's voor ontwikkelingssamenwerking, ongeacht hun partijpolitieke herkomst. Ministers van economische zaken stelden zich nog terughoudender op. 'Where you stand depends on where you sit', luidt één van hun conclusies. ${ }^{38}$ Gelukkig heeft deze politicologische wijsheid een aantal politicologen er niet van weerhouden bijdragen te leveren aan de recente bundel met beknopte biografieën van alle Nederlandse ministers van buitenlandse zaken tijdens de twintigste eeuw. Baehr schreef hierin de bijdrage over minister P. H. Kooijmans (1993-1994) onder de titel 'Pleitbezorger voor de mensenrechten. ${ }^{39}$ Hoezo afnemende betekenis van de mensenrechten?

36 D. ter Brake, P. Klapwijk, 'De Nederlandse ontwikkelingssamenwerking met Nicaragua 1979-1990',

Utrechtse Historische Cahiers, XV (1994) iv.

37 Vgl. C. Klep, R. van Gils, Van Korea tot Kosovo. De Nederlandse militaire deelname aan vredesoperaties sinds 1945 (Den Haag, 1999) 95-154.

38 Baehr, Castermans-Holleman, Grünfeld, Human rights, 231.

39 P. Baehr, 'Pleitbezorger voor de mensenrechten. Pieter Hendrik Kooijmans (1993-1994)', in: Hellema, Zeeman, Van der Zwan, Nederlandse ministers van buitenlandse zaken, 283-295. 
De historici daarentegen schreven veel uitvoeriger dan de politicologen over twee specifiek historische factoren, namelijk de doorwerking van de Tweede Wereldoorlog en de doorwerking van de problematische dekolonisatie van Indonesië. Misschien komt dit omdat de historici in het algemeen veel meer over de Duitse bezetting en de politionele acties gedebatteerd hebben dan de politicologen. Dit ondanks het feit dat de term 'dekolonisatietrauma' door de politicoloog Lijphart ${ }^{40}$ geïntroduceerd werd en dat de belangrijkste historische studie over de doorwerking van de Tweede Wereldoorlog in Nederland door de politicoloog De Haan ${ }^{41}$ geschreven werd. Vooral vanaf de jaren zestig ging de doorwerking van de Duitse bezetting en van de politionele acties, onder invloed van tv-uitzendingen als 'De bezetting' in 1960 en het bekende Hueting-interview in 1969, de aandacht voor mensenrechtenschendingen elders in de wereld bevorderen. ${ }^{42} \mathrm{Zo}$ werd het apartheidsregime zowel tot 'het nazisme van deze tijd' als 'intern kolonialisme' bestempeld in progressieve kring. ${ }^{43}$

Dat ook historici het lang niet eens zijn over de betekenis van verschillende, overwegend interne factoren moge tenslotte blijken uit de meningsverschillen tussen enerzijds Malcontent, De Boer en Baudet en anderzijds mijzelf. In hun dissertaties over het Nederlandse mensenrechtenbeleid ten aanzien van de Derde Wereld, Zuid-Afrika en Oost-Europa kennen ze de mensenrechten als zelfstandige doelstelling veel minder betekenis toe dan ik gedaan heb. Niet alleen was huns inziens deze doelstelling vaak ondergeschikt aan andere doelstellingen, zoals economische belangen, anticommunisme of juist progressieve vooringenomenheid, bovendien werden de mensenrechten soms als dekmantel gebruikt voor dergelijke zwaarder wegende doelstellingen. Zo ziet Baudet de mensenrechten, waarover in het CVSE-proces zo hoog werd opgegeven door Nederland, voornamelijk als een middel om de desintegratie van het Oostblok te bevorderen. ${ }^{44}$ Maar het zelfbeschikkingsrecht en de democratische rechtsstaat die deze desintegratie van het Oostblok voor de voormalige satellieten heeft opgeleverd betekent toch daadwerkelijk een vooruitgang in termen van de internationale mensenrechtenverdragen? Ik zie de tegenstelling tussen anti-communisme als doel en mensenrechten als middel in dit verband niet.

\section{Onontgonnen terrein}

In twee opzichten is er nog veel werk te verrichten bij de politicologische en historische bestudering van de rol van de mensenrechten in het Nederlandse buitenlandse beleid: in de eerste plaats bij de vergelijking van het Nederlandse mensenrechtenbeleid met

40 A. Lijphart, The trauma of decolonization. The Dutch and West Guinea (New Haven, Londen, 1966).

41 I. de Haan, Na de ondergang. De herinnering aan de Jodenvervolging in Nederland 1945-1995 (Den Haag, 1997).

42 De belangrijkste studie over de doorwerking van het dekolonisatietrauma is de recente historische dissertatie van S. Scagliola, Last van de oorlog. De Nederlandse oorlogsmisdaden in Indonesië en hun verwerking (S. 1., 2002).

43 M. Kuitenbrouwer, De ontdekking van de Derde Wereld. Beeldvorming en beleid 1950-1990 (Den Haag, 1994)224.

44 Baudet, Het heeft onze aandacht, 256-257. 
dat van andere westerse landen en in de tweede plaats bij het onderzoek naar de effectiviteit van dat Nederlandse beleid. Dit zijn beide lastige operaties, alleen al om logistieke en bronnentechnische redenen. Toch is er op beide terreinen al een aantal aanzetten gegeven en is er zelfs een enkele pioniersstudie verschenen.

Zo vergeleek Baehr samen met twee Noorse auteurs de verbreking van de ontwikkelingsrelatie met Nederland door Indonesië in 1992 met de verbreking van de ontwikkelingsrelatie met Noorwegen door Kenia in $1990 .{ }^{45}$ In beide gevallen konden de heersende regimes zich vrij gemakkelijk van een kritische maar relatief kleine hulpgever ontdoen, om aldus de nationale soevereiniteit tegenover het binnenlandse publiek te beklemtonen. Meer schetsmatig heb ik zelf de Nederlandse opstelling ten aanzien van de mensenrechten met die van Denemarken en België na 1945 vergeleken. ${ }^{46}$ Die vergelijkende analyse werd verder uitgewerkt voor de ontwikkelingssamenwerking van Nederland en 'gelijkgezinde landen' tussen 1973 en 1985 . $^{47}$

Maar de enige volwaardige, vergelijkende studie over het mensenrechtenbeleid van Nederland, Noorwegen en Canada vanaf het einde van de jaren zeventig tot het begin van de jaren negentig is door de Canadese politicoloog David Gillies geschreven. ${ }^{48}$ Hij baseerde zich eveneens op een theoretisch kader dat voortkwam uit de 'decision making analysis'. Zijn landenkeuze maakt echter duidelijk dat het bij de vergelijking van drie verschillende westerse landen niet eenvoudig is de zelfde onderzoeksobjecten te vinden. Zijn empirische uitwerking laat een bont mozaïek van vergelijkingen zien. Voor Suriname behandelde hij alleen het Nederlandse beleid, voor de Filippijnen vergeleek hij het Nederlandse en Canadese beleid, voor Sri Lanka het Noorse en Canadese beleid, voor Indonesië het Nederlandse en Canadese beleid en voor China tenslotte het beleid van alle drie de landen. In alle landenstudies speelde de ontwikkelingssamenwerking een belangrijke rol en voor Nederland is de belangrijkste conclusie gelegen in het reeds vermelde feit dat Nederland zich als enige hulpgever tegenover Suriname wel een eigenmachtig optreden kon permitteren, maar tegenover Indonesië niet.

Het spoedige herstel van de hulp aan China na het bloedbad op het Tiananmen-plein wees er volgens Gillies op dat alle drie de landen, koplopers op het terrein van de mensenrechten, sterk afhankelijk bleven van hun grote, minder gemotiveerde westerse bondgenoten. In het verlengde daarvan heeft Castermans-Holleman in haar Chinese casestudy duidelijk aangetoond dat deze grote westerse mogendheden meer belang hechtten aan de economische betrekkingen dan aan de mensenrechten, waardoor kleine koplopers als Nederland gemakkelijk geïsoleerd konden worden door China. ${ }^{49}$

45 P. Baehr, H. Selbervik, A. Tostensen, 'Responses to human rights criticism: Kenya-Norway and Indonesia-the Netherlands', in: P. Baehr, e. a., ed., Human rights in developing countries. Yearbook 1995 (Den Haag, Oslo, 1995) 57-87.

46 M. Kuitenbrouwer, 'Nederland en de mensenrechten, 1795-1995', in: Idem, Leenders, Geschiedenis, 198-199.

47 Idem, 'Nederland gidsland? De ontwikkelingssamenwerking van Nederland en gelijkgezinde landen, 1973-1985',. in: J. A. Nekkers, P. A. M. Malcontent, ed., De geschiedenis van vijftig jaar Nederlandse ontwikkelingssamenwerking 1949-1999 (Den Haag, 1999) 183-201.

48 D. Gillies, Between principle and practice. Human rights in North-South relations (Montreal, Kingston, 1996).

49 Baehr, Castermans-Holleman, Grünfeld, Human rights, 149-172. 
In vergelijkend perspectief is overigens ook het uiteenlopende beleid van Canada, de Scandinavische landen en Nederland als koplopers inzake de mensenrechten ten aanzien van Srebrenica interessant. Canada wilde zijn troepen in de onverdedigbare enclave zo snel mogelijk terugtrekken, de Scandinavische landen weigerden in onderling overleg een gemeenschappelijk bataljon te leveren vanwege de grote risico's en Nederland, dat reeds een open aanbod aan de VN gedaan had om een militaire bijdrage aan de vredesmissie in Bosnië te leveren, liet zich met de onmogelijke taak opschepen. ${ }^{50}$

Gillies baseerde zijn vergeüjkende analyse alleen op gedrukte, Engelstalige bronnen en interviews. Voor verdere uitwerking van de vergelijkende analyse zou ook archiefonderzoek in de vergeleken landen wenselijk zijn. Dat zou voor België minder logistieke en taalkundige belemmeringen met zich meebrengen dan met, bijvoorbeeld, de Scandinavische landen - tenzij er een samenwerkingsrelatie met Scandinavische onderzoekers gelegd kan worden, zoals Baehr deed. Maar België is ook om inhoudelijke redenen de moeite van een volwaardige vergelijkende analyse waard. Lange tijd liep het achter op Nederland waar het de ontwikkelingshulp en de mensenrechten betrof, maar onder de nieuwe 'paars-groene' coalitieregering wordt die achterstand snel ingelopen. Het enthousiaste pleidooi voor een vergelijkende conferentie, dat Coolsaet, de auteur van het belangrijkste handboek over het Belgische buitenlandse beleid, hield bij de bespreking van de herdruk van Hellema's handboek, verdient ook wat betreft de mensenrechten bijval. ${ }^{51}$

Een volwaardige analyse van de effectiviteit van het Nederlandse mensenrechtenbeleid is nog moeilijker uit te voeren dan de comparatieve analyse met andere westerse landen. Veelal gaat het hier om ver weg gelegen voormalige dictaturen in Oost-Europa en de niet-westerse wereld. Toch heeft de politicologe Glasius een moedige doch ambitieuze poging in die richting ondernomen. ${ }^{52} \mathrm{Ze}$ onderzocht in haar dissertatie de invloed die westerse hulpgevers, sinds 1966 verenigd in de Inter Governmental Group for Indonesia (IGGI) onder voorzitterschap van Nederland, op de mensenrechtensituatie in Indonesië uitgeoefend hebben tijdens het Suharto-regime. Maar dit onderzoek was weer voornamelijk op gepubliceerde, vooral Engelstalige bronnen en interviews gebaseerd en niet op archiefonderzoek in Jakarta. De zowel in de politicologie als de geschiedschrijving veel gehoorde roep om internationalisering is wel bijzonder klemmend waar het om effectiviteitsonderzoek van Nederlands mensenrechtenbeleid gaat.

\section{Conclusie}

Als we de recente politicologische en historische literatuur over de rol van de mensenrechten in het buitenlandse beleid van Nederland na 1945 overzien, kan men alleen

50 Vgl. Both, From indifference to entrapment, 185-187, 206-207; Bootsma, Srebrenica, 117-122.

51 R. Coolsaet, 'Buitenlandse politiek georganiseerde aanpassing of voortzetting van de binnenlandse politiek?', Internationale Spectator, LVI (2002) 217-219. Vgl. Idem, België en zijn buitenlandse politiek 1830-1990 (Leuven, 1998).

52 M. Glasius, Foreign policy on human rights. Its influence on Indonesia under Soeharto (Antwerpen, Groningen, Oxford, 1999). 
maar verheugd zijn over het multidisciplinaire karakter van dit onderzoeksterrein. Beide disciplines stonden betrekkelijk open voor elkanders analytische concepten en onderzoeksresultaten. Het traditionele beeld van politicologen als abstracte modellenbouwers en historici als ambachtelijke archiefvorsers bleek maar gedeeltelijk op te gaan. De politicologie is in theoretisch opzicht inderdaad meer ontwikkeld dan de geschiedschrijving en historici op het terrein van de mensenrechten hebben hun attenderende begrippen vaak aan de politicologie ontleend. Omgekeerd maakten politicologen dankbaar gebruik van de resultaten van het systematische archiefonderzoek dat door historici verricht werd. Het vruchtbare karakter van deze uitwisseling werd echter mogelijk gemaakt door een min of meer gemeenschappelijk referentiekader. De theoretische oorsprong van de 'decision making analysis' ligt in de Amerikaanse leer van de internationale betrekkingen, maar in feite benaderden traditionele historici als Boogman $^{53}$ en Wels ${ }^{54}$ het buitenlandse beleid van Nederland al op soortgelijke wijze.

Zowel in theoretisch als in empirisch opzicht hebben de politicologie en de geschiedschrijving echter hun relatieve autonomie behouden. Zo hebben historici ook van eigen, specifiek historische concepten gebruik gemaakt, zoals het door De Rooy geïntroduceerde begrip 'burgerlijk beschavingsoffensief', dat ook op het terrein van de mensenrechten vruchtbaar is gebleken. ${ }^{55}$ Op hun beurt hebben de politicologen het interview veel meer als methode van empirisch onderzoek toegepast dan de historici, wat soms opmerkelijke uitspraken opleverde. Meningsverschillen zijn er zeker gebleven bij de analyse van het Nederlandse mensenrechtenbeleid. Maar het debat, bijvoorbeeld over het relatieve gewicht van interne en externe factoren, liep doorgaans door beide disciplines heen.

Het is te hopen dat deze vruchtbare samenwerking tussen historici en politicologen zal worden voortgezet. Ook wanneer deze samenwerking op het nog grotendeels onontgonnen terrein van de vergelijkende analyse en het effectiviteitsonderzoek met collega's uit andere landen zal worden uitgebreid. 'Integratie met behoud van eigen identiteit', zo zou men de verhouding tussen de politicologie en de geschiedwetenschap op het gebied van de mensenrechten kunnen typeren.

53 J. C. Boogman, Nederland en de Duitse Bond 1815-1851 (2 dln.; Groningen, Djakarta, 1955).

54 C.B. Wels, Aloofness and neutrality. Studies on Dutchforeign relations and policy-making institutions (Utrecht, 1982).

55 P. de Rooy, Werkelozenzorg en werkeloosheidsbestrijding 1917-1940. Landelijk en Amsterdams beleid (Amsterdam, 1979) 9-10. Vgl. Kuitenbrouwer, 'Nederland en de mensenrechten', 158-160. 